\title{
Congenital Generalized Hypertrichosis Terminalis with Gingival Hyperplasia and a Coarse Face: a Case Report
}

\author{
Jana KAZANDJIEVA ${ }^{1,}$, Elisaveta STEFANOVA ${ }^{2}, Z_{\text {dravka TODOROVA }}{ }^{1,2}$, \\ Malena NIKOLOVA GERGOVSKA 3 , Kristina SEMKOVA ${ }^{4}$ \\ ${ }^{1}$ Department of Dermatology and Venereology, Medical Faculty, Medical University, Sofia, Bulgaria \\ ${ }^{2}$ Pediatric Clinic, University Hospital "Alexandrovska”, Sofia, Bulgaria \\ ${ }^{3}$ Dermatology Clinic Euroderma, Sofia, Bulgaria \\ ${ }^{4}$ St. John's Institute of Dermatology, Guy's and St. Thomas' Hospital Trust, London, UK \\ *Correspondence: Jana Kazandjieva, E mail: janaderm@abv.bg \\ UDK 616.594-056.7-06:616.311.2 \\ DE GRUYTER
OPEN
}

\begin{abstract}
Congenital generalized hypertrichosis, in its most common form, is idiopathic. In the absence of underlying endocrine or metabolic disorders, congenital generalized hypertrichosis is rare in humans, affecting as few as one in a billion individuals and may be an isolated condition of the skin, or a component feature of other disorders or syndromes. Congenital generalized hypertrichosis terminalis is an extremely rare condition, a distinct subset of disorders with congenital hypertrichosis, presenting with excessive hair as the primary clinical feature. Congenital generalized hypertrichosis terminalis is characterized by universal excessive growth of pigmented terminal hair and often accompanied with gingival hyperplasia and/or a coarse face. Gingival hyperplasia may be delayed even until puberty. Its pathogenesis may be caused by one of the following mechanisms: conversion of vellus to terminal hairs and/or prolonged anagenetic stage, and/or increase in the number of hair follicles. Since the Middle Ages, less than 60 individuals with congenital hypertrichosis terminalis have been described, and, according to the most recent estimates, less than 40 cases were documented adequately and definitively in the literature. Recent articles identified congenital generalized hypertrichosis terminalis as a genomic disorder.

This report is a follow up of a six-year-old boy born from the first normal pregnancy of non- consanguineous parents, starting from delivery. Our investigation revealed a history of: excessive hair growth and a coarse face from birth; increased body weight with high blood pressure and gingival hyperplasia at the age of four months. The parents denied any medication or chemical intake during pregnancy, as well as a history of hypertrichosis in their families. The child had a congenital hydronephrosis of the right kidney. Ultrasound and magnetic resonance imaging revealed severe congenital hydronephrosis of the right kidney and suspicion of hypertrophy of the left adrenal gland suggestive of an adenoma. The follow up showed normal values of hormones which excluded adrenal tumor. At the age of 8 months the patient underwent right-sided nephrectomy after several urinary infections. The child was admitted again to our Clinic at the age of four years, with generalized hypertrichosis, gingival hyperplasia and a coarse face without any other pathological signs. He has had a normal intellectual development, but was extremely shy, unconfident and dependent on his mother. The relevant laboratory investigations showed normal full blood count, biochemical, hormonal test results and normal function of the single kidney. Molecular chromosome analysis revealed heterozygous deletion on chromosome 17q12 region. Prolonged follow-up with routine checkups every 6-12 months was advised, including regular outpatient appointments particularly with an endocrinologist, because of the risk of diabetes mellitus, and with a nephrologist, for control of renal function.

Laser hair removal was suggested and the patient underwent one procedure with long pulsed neodynium:yttrium-albumingarnet laser with a wavelength of $1064 \mathrm{~nm}$. The procedure was effective and well-tolerated and the treatment course is currently ongoing.

Although it is now believed that most people with congenital generalized hypertrichosis have an unknown genetic defect, up to date, a clear specific molecular abnormality has not been proved. It has been suggested that the distal portion of human chromosome 17q may contain dosage-sensitive genes that contribute to excessive hair growth.

We present a sporadic case of an extremely rare congenital generalized hypertrichosis terminalis in a six-year-old boy born to non-consanguineous parents, with gingival hyperplasia, a coarse face and congenital hydronephrosis, with heterozygous deletion on chromosomal region $17 q 12$ consistent with his renal phenotype.
\end{abstract}

\section{Key words}

Hypertrichosis + congenital; Gingival Hyperplasia; Chromosomes, Human, Pair 17 + genetics; Child; Hydronephrosis; Case Reports 
$\mathrm{H}$ ypertrichosis $(\mathrm{H})$ refers to increased androgenindependent lanugo, vellus or terminal hair, associated with numerous pathological conditions and heterogeneous etiological disorders. $\mathrm{H}$ may be generalized or circumscribed, congenital or acquired where congenital is loosely interpreted as that seen in early infancy $(1,2,3)$. The clinical pattern of hypertrichosis varies, ranging from lanugo, to vellous and terminal hairs (4).

Congenital generalized hypertrichosis (CGH) is a rare group of phenotypically and genetically heterogeneous conditions, most frequently present at birth, characterized by excessive hair growth all over the body as compared to the normal of the same age, sex, and race (5). CGH in its most common form is idiopathic in the absence of underlying endocrine or metabolic disorders. In the past, many cases of excessive hairiness caused by congenital, metabolic or endocrine disorders, including androgen-dependent, were considered to be congenital generalized hyper-trichosis. There are more than 29 different terms in the literature: "bear man", "dog man", "ape man"; "wild man", human Skye terriers, werewolves, and Homo sylvestris. Idiopathic CGH is assumed to be related to an excess of stimulation of the hair follicles with normal levels of androgen-like hormones and it may be a classical example of an atavistic reversion of a suppressed ancestral gene (4). Although it is now believed that most people with $\mathrm{CGH}$ have an unknown genetic defect, up to date, a clear specific molecular abnormity has not been established (4). However, specific molecular defects have been reported in well-known syndromes presenting with hypertrichosis (4).

CGH is rare in humans and it affects as few as one in a billion individuals and may be an isolated condition of the skin or a component feature of other disorders. The incidence is higher if $\mathrm{CGH}$ is one of several signs involved in a syndrome. In this case, the incidence of $\mathrm{CGH}$ is related to the single condition associated with it (4). In idiopathic CGH, an autosomal dominant $(\mathrm{AD})$ trait inheritance, autosomal recessive (AR) pattern of inheritance, as well as an involvement of chromosome X at the locus Xq24-q27.1 have been described. Although many additional anomalies are associated with hypertrichosis, only a distinct subset of disorders presents with an excessive hair as the primary clinical feature, this includes the following: congenital hypertrichosis lanuginose, which is thought to occur as an autosomal dominant trait with variable expressivity; if it is possible to make distinction between lanugo and vellus hair, those with vellus hair may be classified as a form of universal hypertrichosis known as autosomal dominant Ambras syndrome, or congenital hypertrichosis universalis which is a subtype of a unique congenital hypertrichosis universalis, that is associated with a balanced pericentric inversion on chromosome 8 (p11.2; q22); $\mathrm{X}$-linked generalized hypertrichosis and congenital generalized hypertrichosis terminalis (CGHT) with or without gingival hyperplasia $(1,6,7)$.

Congenital generalized hypertrichosis terminalis (CGHT) is an extremely rare condition characterized by universal excessive growth of pigmented terminal hairs and often accompanied with gingival hyperplasia and/or a course face $(5,8)$. Gingival hyperplasia may be delayed even until puberty. Its pathogenesis may be caused by one of the following mechanisms: conversion of vellus to terminal hairs and/or prolonged anagenetic stage, and/or increase in the number of hair follicles. Since the Middle Ages, less than 60 individuals with congenital hypertrichosis terminalis have been described, and, according to the most recent estimates, less than 40 cases were documented adequately and definitively in the literature $(9,8,10-14)$. Recent articles identified CGHT as a genomic disorder (8). It has been suggested that the distal portion of human chromosome $17 \mathrm{q}$ may contain dosage-sensitive genes that contribute to excessive hair growth (7).

\section{Case report}

This report is a follow up of a six-year-old boy comming from the first normal pregnancy of nonconsanguineous parents, starting from delivery. The study revealed a history of excessive hair growth and a coarse face from birth; increased body weight with high blood pressure and gingival hyperplasia at the age of four months. The parents denied any medication or chemical intake during pregnancy, as well as a history of hypertrichosis in the family. The child had congenital hydronephrosis of the right kidney. Imagining studies, including ultrasound and magnetic resonance imaging (MRI) revealed severe congenital hydronephrosis of the right kidney and suspicion of hypertrophy of the left adrenal gland suggestive of an adenoma. The 
follow up showed normal values of hormones which excluded adrenal tumor. At the age of 8 months the patient underwent right-sided nephrectomy after several urinary infections. The child was admitted again to our Clinic at the age of four years, with generalized hypertrichosis, gingival hyperplasia and a coarse face without any other pathological signs. He has had a normal intellectual development, but was extremely shy, unconfident and dependent on his mother.

\section{Physical examination at the age of four months}

On examination there were distinct facial features prominent and broad forehead, very broad nose with a round tip, full lips, abundant facial hair with thick eyebrows and eyelashes, profuse hair on the upper and lower limbs and on the back (Figure 1). Pulmonary and cardiovascular functions were normal, except for several readings of high blood pressure. The differential diagnosis included: androgen producing adrenal gland or ectopic tumor, Cushing syndrome, or syndromes with CGHT.

\section{Laboratory and other test results soon after delivery}

Laboratory tests revealed the following abnormal results: serum testosterone level $2.32 \mathrm{nmol} / \mathrm{l}$ (normally less than $1,0 \mathrm{nmol} / \mathrm{l}$ ), serum dehydroepiandrosterone sulphate level (DHEAS) $0.18 \mu \mathrm{g} / \mathrm{ml}$ (normally 0.25 $-1.0 \mu \mathrm{g} / \mathrm{ml}$ ) and cortisol at $8 \mathrm{~h} \mathrm{A.} \mathrm{M.} 166.3 \mathrm{nmol} / \mathrm{l}$ (normally 244 - 727). Chromosomal analysis revealed $46, \mathrm{XY}$, with abnormal rearrangement in the 13 and 14 chromosome pair [der (13; 14) (q10; q10)].

The ultrasound and magnetic resonance imaging (MRI) revealed severe congenital hydronephrosis of the right kidney and suspicion of hypertrophy of the left adrenal gland suggestive of an adenoma. The follow up showed normal values of hormones and excluded adrenal tumor. At the age of 8 months the patient underwent right-sided nephrectomy, after several urinary infections.

\section{Physical examination at the age of four years}

On examination, there were aformentioned distinct facial features with generalized hypertrichosis and gingival hyperplasia without any other pathological signs (Figures 2 and 3). The gingival hyperplasia was more prominent but did not progress to the extent that could interfere with tooth eruption and feeding.

\section{Laboratory tests at the age of four years}

The relevant laboratory tests showed normal full blood count, biochemical, hormonal laboratory analyses and normal function of the single kidney.

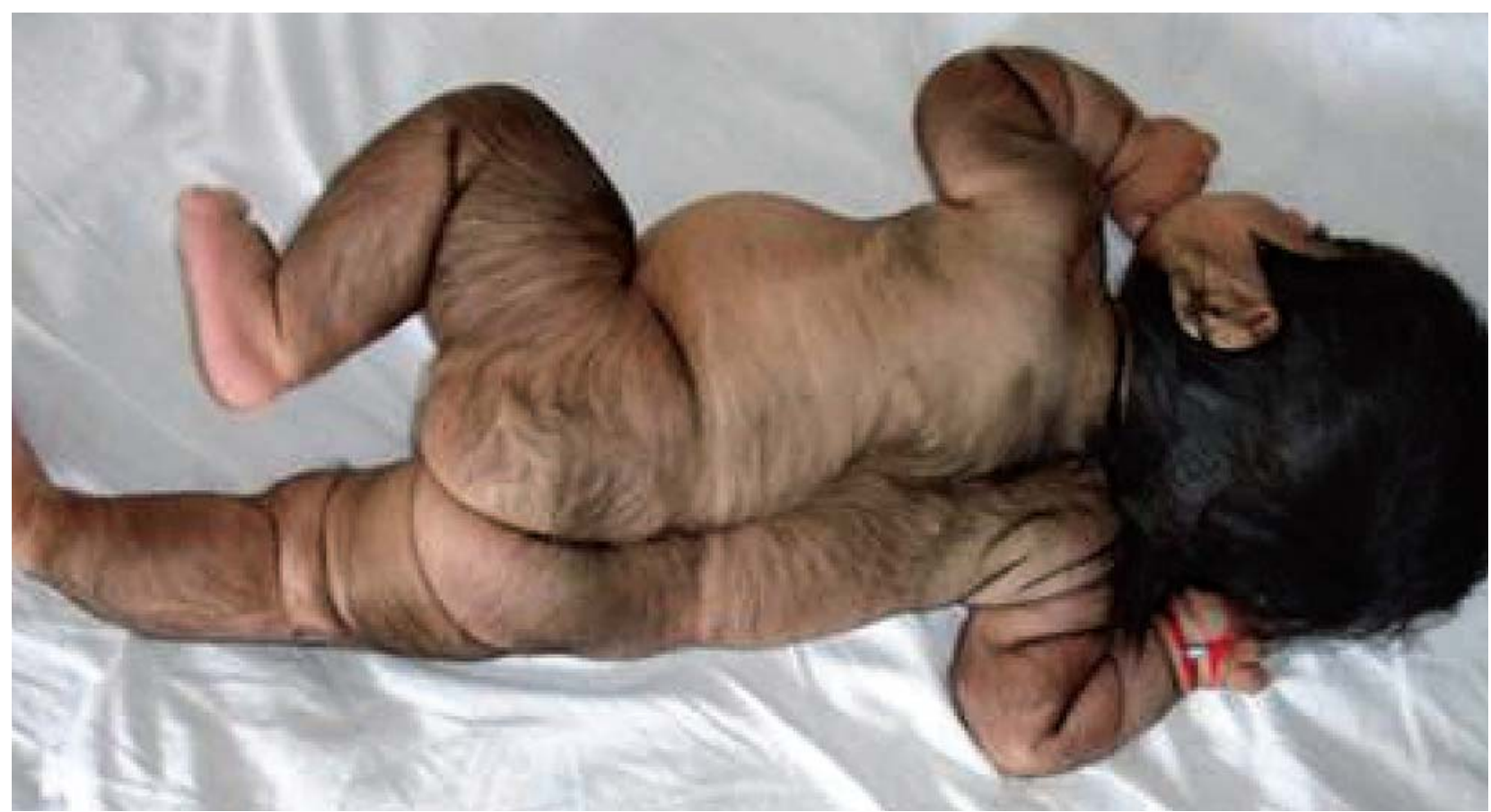

Figure 1. Physical examination at the age of four months showing profuse hair on the upper and lower limbs and on the back 
Molecular chromosome analysis revealed heterozygous deletion on chromosome $17 \mathrm{q} 12$ region.

Prolonged follow-up with routine checkups every 6-12 months was advised, including regular outpatient appointments particularly with an endocrinologist due to the risk of diabetes mellitus, and a nephrologist for control of renal function.

\section{Therapy}

Laser hair removal was suggested and the patient underwent one procedure with long pulsed neodynium: yttrium-albumin-garnet (Nd:YAG) laser with a wave length of $1064 \mathrm{~nm}$.

The procedure was effective and well-tolerated and the treatment course is currently ongoing.

\section{Discussion}

Hypertrichosis has been described in many genetic disorders, but CGHT with or without gingival hyperplasia is considered an extremely rare form. A literature review done by Afifi et al. revealed only five reports of seven families with generalized hypertrichosis with or without gingival hyperplasia and/or a coarse face $(7,8,9,1113)$.

Recently, a series of deletions and duplications greater than 1,000 nucleotides, called copy number variants (CNVs) were reported in CGHT. In 2009, Sun et al. identified three Han Chinese families and 22 affected members with CGHT, a coarse face but no gingival hyperplasia, non-recurrent microdeletions on chromosome 17q24.2-q24.3 and one, de novo microduplication within this same region on chromosome 17, in one sporadic case of CGHT with a course face and gingival hyperplasia (8). The minimal $555 \mathrm{~kb}$ region common to each of these cases encompassing four genes: ABCA6, ABCA10, ABCA5, and MAP2K6, suggested that disruption of one of these genes may operate in the CGHT phenotype. The region was identified $2.5 \mathrm{Mb}$ upstream of SOX9, a gene previously shown to be required for the specification and maintenance of hair follicle stem cells in mice (8).

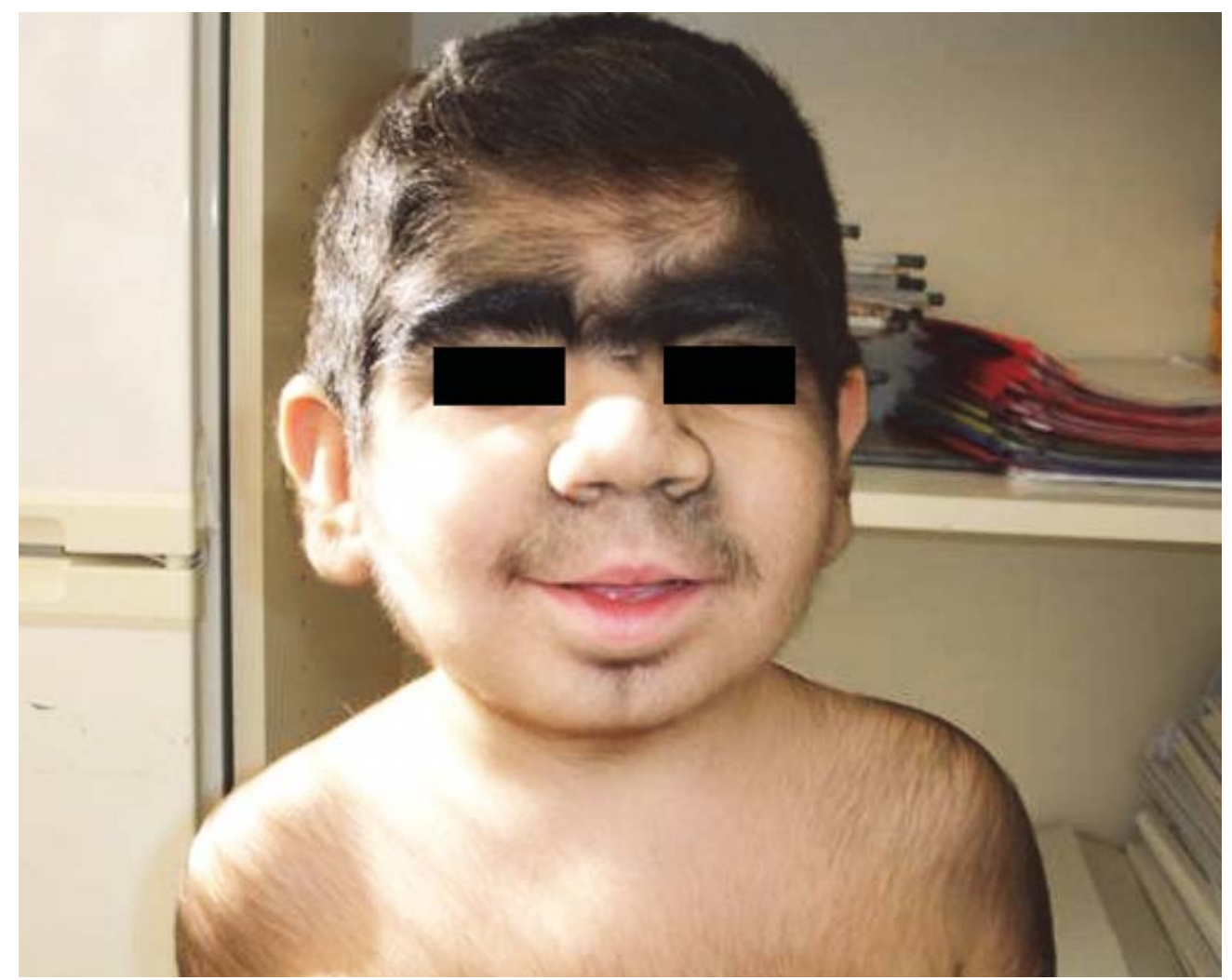

Figure 2. Physical examination at the age of four years revealed a distinctive coarse face with: bilateral epicanthic folds, prominent and broad forehead, very broad nose with a round tip, full cheeks and lips, abundant facial hair with thick eyebrows and eyelashes 


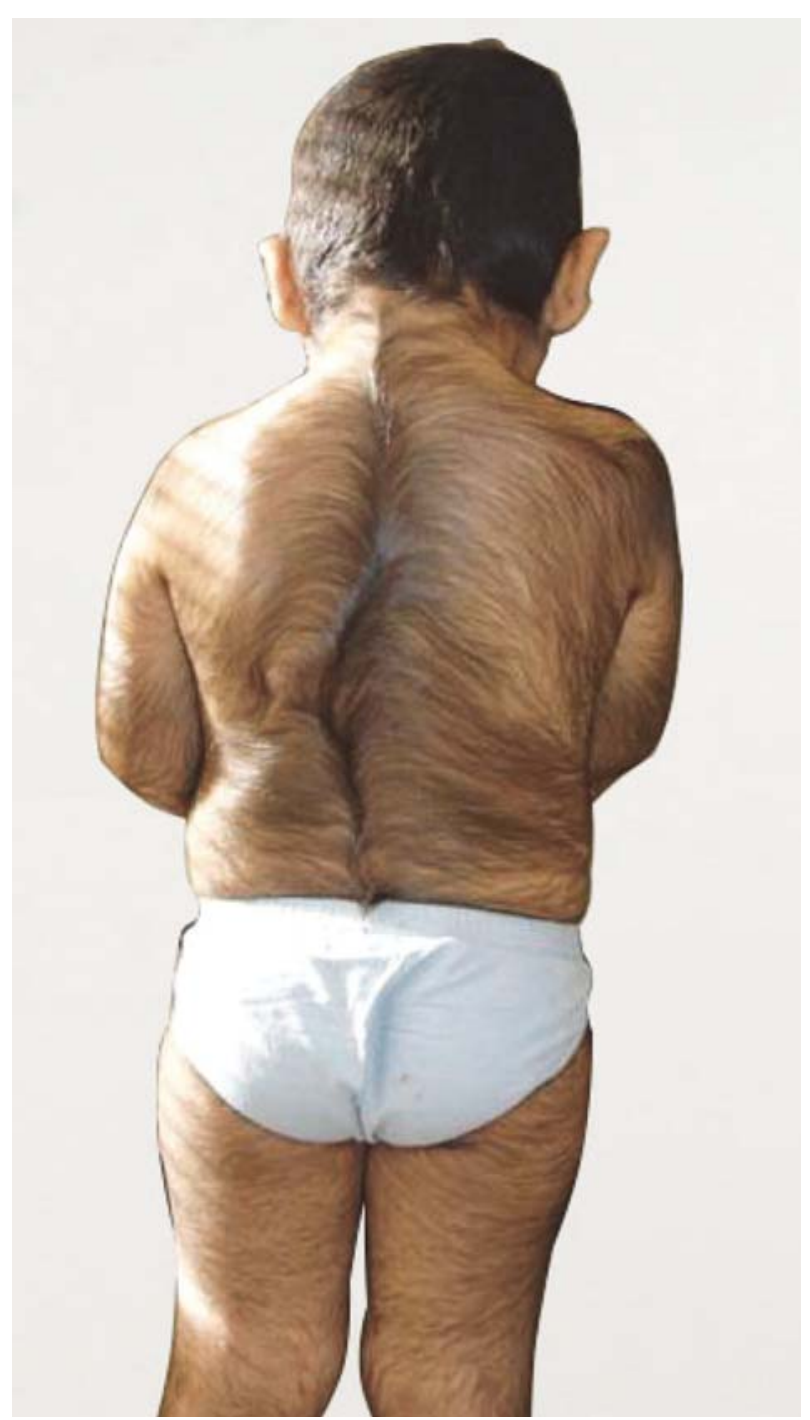

Figure 3. Physical examination at the age of four years revealed profuse hair on the upper and lower limbs and on the back

In 2012, Fantauzzo et al. also identified a series of four microduplications on chromosome 17q24.2-q24.3 in a father and son who both presented with CGHT and a coarse face and mild gingival hyperplasia, and reported a position effect on the SOX9 gene, situated $1 \mathrm{Mb}$ downstream of these variants (7). These results and the previously reported pedigrees supported the $\mathrm{AD}$ inheritance of $\mathrm{CGHT}(7,8)$. An Irish family with CGHT presented with a coarse face and normal gingivae, $\mathrm{AD}$ has also been observed (14), but genetic linkage to 17 q24.2-q24.3 was excluded after haplotype analysis. Moreover, further genome-wide linkage scan in this family yielded a maximum but not statistically significant probability score of genetic linkage with single nucleotide polymorphism (SNP) markers on a chromosome 6 region, pointing to the presence of genetic heterogeneity in AD-CGHT with a coarse face (8). Although a wide family genome-linkage scan is lacking in our case, our results also substantiate this observation, since chromosomal analysis in our patient revealed the two following abnormalitie: 46, XY, with abnormal rearrangement in the 13 and 14 chromosome pair [der (13;14) (q10;q10)] and heterozygous deletion on chromosome $17 \mathrm{q} 12$ region. The first abnormality was not consistent with the phenotype, but with the presence of so-called Robertsonian translocation. The latter represents a rare significant form of chromosomal rearrangement; in humans it occurs in the five acrocentric chromosome pairs, namely 13, 14, 15, 21 and 22 ; it is produced by fusion of the whole long arms of two acrocentric chromosomes with the centromere near the very end. The second abnormality is consistent with the kidney phenotype of our patient. Several new microdeletion and microduplication syndromes, including $17 \mathrm{q} 12$ deletion/duplication, have been proven to cause multiple congenital anomalies (MCA). Apart from diaphragmatic hernia, genital disorders in females and pulmonary cysts, deletion producing MCA also include renal cysts which can cause obstruction/ hydronephrosis (15).

Another rare form of CGHT with gingival hyperplasia was previously described showing AR mode of inheritance $(11,12,16)$. DeStefano et al. identified two girls with CGHT. The first with gingival hyperplasia and normal face was from a consanguineous family for whom whole-exome sequencing revealed a novel, rare homozygous variant of ABCA5 gen, demonstrating AR mode of inheritance. The second girl represented an unrelated case with gingival hyperplasia and a coarse face, showed a $[\mathrm{t}(3 ; 17)]$ translocation and cryptic 1.3 megabase $(\mathrm{Mb})$ deletion involving $\mathrm{ABCA} 5$ gen, demonstrating $\mathrm{AD}$ mode of inheritance, indicating that ABCA5 defects might be the primary cause of many features of the CGHT phenotype (11). Furthermore, significantly reduced levels of ABCA5 transcripts and transcribed proteins in the patient's hair follicles suggested an important role of $A B C A 5$ in hair growth regulation (11). Therefore, ABCA5 has attracted the most attention as a causative gene for either AR- or AD-CGHT (11). An overlap between AD and AR inheritance pattern is apparent at the phenotypic 
and pathological level, suggesting a common genetic background. Nevertheless, the presence or absence of gingival hyperplasia among patients with $\mathrm{CNVs}$ also present in our case is still not yet completely understood, because of the limited number of patients. Interestingly, all reported microdeletion patients did not manifest gingival hyperplasia $(8,11,14)$. In comparison, patients with microduplication showed gingival hyperplasia of variable severity. Although an Egyptian female patient, reported by Afifi et al, as well as our patient with CGHT also had a microdeletion, they both apparently presented with gingival hyperplasia (10). Such a correlation between genomic alterations and phenotype is not well understood. Afifi et al. suggested that these might be partially explained by the observation that reciprocal deletion and duplication syndromes usually present with abnormalities of the same organs or functions exhibit different clinical severity and penetrance $(10,17)$. Despite the identification of CNVs and/or position effects in this region on chromosome 17q24.2-q24.3, no point mutations in these or any other single genes have been described to underlie the CGHT phenotype (11).

In regard to the association between CGHT and a characteristic coarse face, Laurence [1857] was the first to describe a Mexican lady with a congenital generalized hypertrichosis terminalis (CGHT) with gingival hyperplasia and a distinctive coarse face showing bilateral epicanthic folds, thick and abundant eyelashes, broad nose, full cheeks, and lips (18). These coarse facial features were similarly observed in all patients with CNVs on 17q24.2-q24.3 with $(7,8,9$, $11,13)$ or without gingival hyperplasia $(8,11,14)$. In contrast, DeStefano et al. (11), as well as Anavi et al., (12) and Douzgou et al. (16), did not describe these coarse features in an AR patient with CGHT. Based on his own observations, Afifi stated that patients with AR type disease lacked the characteristic coarse facial features seen in the AD type (10). He stated that the distinctive facial and oro-dental features might be used as a specific morphological characteristic to describe AD-CGHT and gingival hyperplasia. However, further studies are needed to clarify the role of the genes located within 17q24.2- q24.3 in the pathogenesis of CGHT. Moreover, several new microdeletion and microduplication syndromes, including 17q12 deletion/ duplication, have been proven to cause multiple congenital anomalies (MCA), autistic spectrum disorders (ASD) and other phenotypic findings, associated with intellectual disability (ID). Deletion presents congenital disorders such as diaphragmatic herniae, pulmonary cyst and renal disorders as in our patient (15).

The diagnosis of CGH should be based on a detailed history, with special attention given to the presence of other anomalies, particularly of the face, teeth, and kidneys (4). The differential diagnosis should distinguish CGH from the acquired forms such as drug induced, particularly due to phenytoin, corticosteroids, cyclosporine and interferon alpha; consequences of malnutrition and anorexia nervosa, endocrine disorders, metabolic diseases such as congenital porphyrias, and adrenal enzymatic deficiency, ovarian and adrenal neoplasms as in our case. The prognosis depends on the associated pathological events.

CGH may cause significant emotional distress, not only in the affected patient, but his family as well. There are different approaches to the treatment of excess hair, including: cosmetic procedures such as electrosurgical epilation, pulsed light source, treatment with ruby, alexandrite, diode and especially neodynium:yttrium-albumin-garnet (Nd:YAG) laser, as in our case, and pharmacological treatment. It should be underlined that not all treatments are effective in the long run, and the choice of therapy should be made accordingly. Pharmacological treatment consists of topical eflornithine, a specific and irreversible inhibitor of the enzyme ornithine decarboxylase, which is located within the hair follicle stimulating hair growth. In general, good results can be obtained, but in approximatelly one third of cases hair regrowth occurs, thus necessitating further procedures (4).

\section{Conclusion}

We present a sporadic case of extremely rare congenital generalized hypertrichosis terminalis in a six-year-old boy born to non-consanguineous parents with a coarse face, gingival hyperplasia, and congenital hydronephrosis, with heterozygous deletion on $17 \mathrm{q} 12$ chromosome region consistent with his kidney phenotype.

\section{Abbreviations}

$\mathrm{H}$ - hypertrichosis

$\mathrm{CGH}$ - congenital generalized hypertrichosis

$\mathrm{AD}$ - autosomal dominant 
AR - autosomal recessive

CGHT - congenital generalized hypertrichosis terminalis

MRI - magnetic resonance imaging

DHEAS - dehydroepiandrosterone sulphate level

A.M. - ante meridiem, meaning before midday

CNVs - copy number variants

$\mathrm{Kb}$ - kilobase

$\mathrm{Mb}$ - megabase

SNP - single nucleotide polymorphism

MCA - multiple congenital anomalies

ASD - autistic spectrum disorders

ID - intellectual disability

Nd:YAG - neodynium:yttrium-albumin-garnet

\section{References}

1. Messenger AG, de Berker DA, Sinclair RD. Disorders of hair. In: Burns T, Breathnach S, Cox N, Griffiths C, editors. Rook's textbook of dermatology. $8^{\text {th }}$ ed. Oxford: Blackwell Publishing Ltd; 2010. p. 66.1-66.100.

2. Ngan V. Hypertrichosis. DermNet NZ .org [home page on the Internet] [updated $2016 \mathrm{Feb}$, cited 2016 Jun 9]. Available from: http://dermnetnz.org/hair-nails-sweat/hypertrichosis.html

3. Sutton RL. Diseases of the skin. St. Louis: C.V. Mosby Company; 1916. p. 408. [cited 2016 Jun 9]. Available from: https://archive.org/stream/diseasesskin02suttgoog\#page/n20/ mode/2up

4. Pavone P, Praticò AD, Falsaperla R, Ruggieri M, Zollino M, Corsello G, et al. Congenital generalized hypertrichosis: the skin as a clue to complex malformation syndromes. Ital J Pediatr 2015;41:55.

5. Wendelin DS, Pope DN, Mallory SB. Hypertrichosis. J Am Acad Dermatol 2003;48(2):161-79.

6. Paus R, Olsen EA, Messemger AG. Hair growth disorders. In: WoIff $K$, Lowell A, Katz GS, Gilchrest BA, Paller AS, Leffell DJ, editors. Fitzpatrick's dermatology in general medicine. $7^{\text {th }} \mathrm{ed}$. New York: McGraw-Hill; 2008. p. 753-77.

7. Fantauzzo KA, Kurban M, Levy B, Christiano AM. Trps1 and its target gene Sox9 regulate epithelial proliferation in the developing hair follicle and are associated with hypertrichosis. PLoS Genet 2012;8(11):e1003002.

8. Sun M, Li N, Dong W, Chen Z, Liu Q, Xu Y, et al. Copy-number mutations on chromosome $17 \mathrm{q} 24.2-\mathrm{q} 24.3$ in congenital generalized hypertrichosis terminalis with or without gingival hyperplasia. Am J Hum Genet 2009;84(6):807-13.

9. Bondeson J, Miles AE. Julia Pastrana, the nondescript: an example of congenital, generalized hypertrichosis terminalis with gingival hyperplasia. Am J Med Genet. 1993;47(2):198-212.

10. Afifi HH, Fukai R, Miyake N, Gamal el Din AA, Eid MM, Eid OM, et al. De Novo 17q24.2-q24.3 microdeletion pre-senting with generalized hypertrichosis terminalis, gingival fibromatous hyperplasia, and distinctive facial features. Am J Med Genet A 2015;167A(10):2418-24.

11. DeStefano GM, Kurban M, Anyane-Yeboa K, Dall'Armi C, Di Paolo G, Feenstra H, et al. Mutations in the cholesterol transporter gene ABCA5 are associated with excessive hair overgrowth. PLoS Genet 2014;10(5):e1004333.

12. Anavi Y, Lerman P, Mintz S, Kiviti S. Idiopathic familial gingival fibromatosis associated with mental retardation, epilepsy and hypertrichosis. Dev Med Child Neurol 1989;31(4):538-42.

13. Canun S, Guevara-Sangines EG, Elvira-Morales A, Sierra-Romero Mdel C, Rodriguez-Asbun H. Hypertrichosis terminalis, gingival hyperplasia, and a characteristic face: a new distinct entity. Am J Med Genet 2003;116A(3):278-83.

14. Irvine AD, Dolan OM, Hadden DR, Stewart FJ, Bingham EA, Nevin NC. An autosomal dominant syndrome of acromegaloid facial appearance and generalised hypertrichosis terminalis. J Med Genet 1996;33(1):972-4.

15. Nevado J, Mergener R, Palomares-Bralo M, Souza KR, Vallespín E, Mena R, et al. New microdeletion and microduplication syndromes: a comprehensive review. Genet Mol Biol 2014;37(1 Suppl):210-9.

16. Douzgou S, Mingarelli R, Dallapiccola B. Gingival overgrowth, congenital generalized hypertrichosis, mental retardation and epilepsy: case report and overview. Clin Dysmorphol 2009;18(4):205-8.

17. Stankiewicz P, Pursley AN, Cheung SW. Challenges in clinical interpretation of microduplications detected by array $\mathrm{CGH}$ analysis. Am J Med Genet A 2010;152A(5):1089-100.

18. Laurence JZ. A short account of the bearded and hairy female. Lancet 1857;7(1767):48.

\section{Kongenitalna generaliziovana terminalna hipertrihoza udružena sa gingivalnom hiperplazijom i grubim crtama lica - prikaz slučaja}

\section{Sažetak}

Uvod. Kongenitalna generalizovana hipertrihoza najčešće je idiopatska. U odsustvu relevantnih metaboličkih i endokrinih poremećaja, ona je izuzetno retka, procenjuje se da pogađa jednu među bilion osoba. Istovremeno može predstavljati izolovani poremećaj u koži ili biti deo različitih sindroma. Kongenitalna generalizovana terminalna hipertrihoza se ekstremno retko javlja, a pripada grupi onih oboljenja u kojima prekomerni porast dlake predstavlja primarni poremećaj. Karakteriše je prekomerni rast pigmentovane terminalne dlake i često je udružena sa gingivalnom hiperplazijom koja se može javiti kasnije, ponekad čak u pubertetu. U 
patogenetskom smislu može biti posledica jednog od sledećih mehanizama: prelaz velus dlake u terminalnu i/ili produženje anagenskog stadijuma, i/ili povećanje broja folikula dlake. Počevši od srednjeg veka pa do današnjih dana, opisano je manje od 60 obolelih, od kojih je samo 40 adekvatno dokumentovano. Rezultati novijih istraživanja ukazuju na genetsku etiologiju.

Prikaz slučaja. U ovom radu, autori prikazuju slučaj šestogodišnjeg dečaka čiju bolest prate od prvih dana posle rođenja. Dečak je rođen u nekonsangvinom braku u prvoj trudnoći, koja je protekla bez poremećaja. $\mathrm{Na}$ rođenju, kod deteta je bio prisutan univerzalan prekomeran rast pigmentovane terminalne dlake, karakteristične grube crte lica, povišen krvni pritisak, a nakon četiri meseca, pored povišene telesne težine, došlo je do pojave hiperplazije gingiva. Roditelji su negirali upotrebu bilo kog leka ili hemikalija za vreme trudnoće majke i prisustvo hipertrihoze u porodici. Laboratorijska ipitivanja koja su odstupala od fizioloških vrednosti odnosila su se na povišen nivo testosterona u serumu koji je iznosio 2,32 nmol/l (normalno manje od $1 \mathrm{nmol} / \mathrm{l}$ ), serumskog nivoa dehidroepiandrosteron sulfata u iznosu od $0,18 \mu \mathrm{g} / \mathrm{ml}$ (normalno $0,25-1 \mu \mathrm{g} / \mathrm{ml}$ ) i smanjenog nivoa kortizola u 8 h ujutro koji je iznosio 166,3 nmol/l (normalno 244-727). Analizom hromozoma pored kariotipa 46, XY, utvrđeno je postojanje rearanžmana između hromozoma 13 i 14 [der (13;14) (q10;q10)] čime se mogla objasniti pojava kongenitalne hidronefroze.

Zbog kongenitalne hidronefroze desnog bubrega i nekoliko epizoda pijelonefritisa, dečaku je u osmom mesecu života odstranjem desni bubreg.

Ultrazvučna i radiološka ispitivanja, kao i magnetna rezonancija ukazala su na postojanje teškog oblika kongenitalne hidronefroze, kao i sumnju na postojanje hipertrofije/adenoma leve nadbubrežne žlezde. Rezultati redovnih laboratorijskih kontrolnih hormonalnih analiza, koje su potom usledile, bili su u granicama fizioloških vrednosti, a sumnja o postojanju adenoma je isključena.

U četvrtoj godini života, dete je ponovo hospitalizovano $\mathrm{u}$ našoj ustanovi. Pored generalizovane hipertrihoze, grubih crta lica i hiperplazije desni, nije bilo drugih poremeća. Iako je intelektualni razvoj bio neometan, dete je bilo ekstremno stidljivo, nesigurno i zavisno od svoje majke.

Relevantne laboratorijske analize uključujući i hormonske, bile su uz očuvanu funkciju preostalog levog bubrega i dalje u granicama normale. Molekularna genetska analiza hromozoma ukazala je na postojanje heterozigotne delecije na hromozomskoj 17q12 regiji.

Planiran je nastavak sprovođenja redovnih kontrolnih pregleda svakih 6-12 meseci uključujući pored dermatologa, pedijatra-nefrologa sa ciljem kontrole renalne funkcije i dijabetologa zbog postojanja povišenog rizika za dobijanje dijabetesa melitus.

Kod dečaka je započeto lečenje uklanjanjem dlaka pomoću neodinijum:itrijum-albumin-garnet lasera talasne dužine 1064. Lečenje se pokazalo efikasnim i njegovo sprovođenje je i dalje u toku.

Diskusija. Iako se danas smatra da se u osnovi većine slučajeva kongenitalne generalizovane hipertrihoze nalazi genetski poremećaj, njegova specifičanost na molekularnom nivou još uvek nije potvrđena. Pretpostavlja se da se geni koji pospešuju prekomerni porast dlake kod ljudi, nalaze na distalnom delu hromozoma $17 \mathrm{q}$.

Zaključak. U radu je prikazan ekstremno redak slučaj kongenitalne generalizovane terminalne hipertrihoze kod šestogodišnjeg dečaka sa kongenitalnom gingivalnom hiperplazijom i karakterističnim grubim crtama lica, rođenog u nekonsangvinom braku, kod koga je utvrđeno prisustvo heterozigotne delecije na hromozomskoj regiji $17 \mathrm{q} 12$ koja je rezultirala pojavom kongenitalne hidronefroze.

Ključne reči: Hipertrihoza + kongenitalna; Gingivalna hiperplazija; Humani hromozomi, par 17 + genetika; Dete; Hidronefroza; Prikazi slučajeva 